\title{
Effects of Thermal Treatment before Plane Sanding on the Surface Quality of Corymbia citriodora Wood
}

\author{
Larissa Ribas de Lima Soares, ${ }^{\mathrm{a}, *}$ Carlino Carvalho de Almeida, ${ }^{\mathrm{b}}$ Manoel Cléber de \\ Sampaio Alves, ${ }^{a}$ Bruno Santos Ferreira, ${ }^{a}$ and Alexandre Camargo da Silva ${ }^{b}$
}

\begin{abstract}
Wood sanding is one of the most expensive processes in the woodworking industry, and little is known about the factors that influence the final quality of wooden parts. For this reason, studies involving different wood treatments, such as thermal treatment, have been developed to produce better surface qualities. The objective of this work was to verify the influence of thermal treatment of the wood species Corymbia citriodora before the sanding process on the surface quality of the wood pieces. The surface finishes of the sanded natural and heat-treated wood were compared. Sanding was performed using two sandpaper grades, 80 mesh and 120 mesh, with abrasive grains of aluminum oxide. The sanding process was performed by flat horizontal sanding parallel to the fibers. Six specimens were used for each sandpaper grade. Initially the specimens were heat-treated at $120^{\circ} \mathrm{C}, 160^{\circ} \mathrm{C}$, and $200^{\circ} \mathrm{C}$ for $2 \mathrm{~h}$, and then they were subjected to sanding. For the analysis of the surface quality of the wood pieces, the average roughness was used. From the obtained results, it was concluded that the heat treatment considerably reduced the roughness of the wood for both sandpaper grit sizes, and it facilitated the final finishing of the wood pieces.
\end{abstract}

Keywords: Sanding process; Heat treatment; Superficial finishing; Roughness $\left(R_{a}\right)$

Contact information: a: Department of Mechanical Engineering, São Paulo State University (UNESP), Avenida Ariberto Pereira da Cunha, 333, Guaratinguetá/SP, Brazil; b: São Paulo State University (UNESP), Campus of Itapeva, Rua Geraldo Alckmin, 519, Itapeva/SP, Brazil;

* Corresponding author: larissa.ribas.lima@ gmail.com

\section{INTRODUCTION}

Sanding improves the surface of wood, and this process is essential when a wood piece needs to go through a later stage of varnishing or painting. A good sanding process ensures a better penetration and uniformity of the varnish or paint products applied on the wood material (Hendarto et al. 2004). The wood sanding process is difficult to characterize and analyze because of the random nature and distribution of grains in the sandpaper. In the case of sanding heterogeneous materials, such as wood, the complexity of the process increases and many conditions must be considered (Saloni et al. 2010). There are several methods for sanding wood, such as horizontal and vertical flat sanding, but little is known about the effect of wood treatment, such as heat treatment, on the wood sanding quality.

The heat treatment of wood provides a method for controlled degradation of wood material. This process normally occurs in the absence of oxygen or air and promotes the decomposition of the chemical constituents, mainly hemicellulose. Changes in the properties will occur according to the temperature used during treatment (Rodrigues 2009; Navi and Sandberg 2012). 
During heat treatment, an increase in the cellulose crystallinity occurs in the wood because of the degradation of the amorphous regions and reorganization of the cellulose molecules (Bhuiyan et al. 2000; Wikberg and Maunu 2004; Yildiz and Gümüşkaya 2007). However, Poubel et al. (2013) reported a noteworthy reduction in the crystalline cellulose content starting at $220{ }^{\circ} \mathrm{C}$. Because the cellulose crystallinity is considered to be the main factor responsible for the resistance of wood fiber, this resistance decreases when the degree of polymerization of the cellulose decreases (Sweet and Winandy 1999).

Polyoses (hemicelluloses) begin to degrade at a temperature above $190{ }^{\circ} \mathrm{C}$. Thus, hemicellulose degradation begins before cellulose degradation. This is because of the lower thermal stability of hemicelluloses compared with that of cellulose caused by their amorphous structure (Yildiz et al. 2006; González-Peña et al. 2009; Kačíková et al. 2013). With the degradation of hemicellulose, the cell wall absorbs less water because of a decrease in $\mathrm{OH}$ groups (hydroxyls); thus, a reduction in the swelling and retraction of the wood occurs, which implies a greater dimensional stability (Gündüz et al. 2008).

Molina and da Silva (2012) studied the effects of thermal treatment on the resistance and rigidity properties of Eucalyptus citriodora wood. In their work, wood samples were heat-treated at $160{ }^{\circ} \mathrm{C}, 180{ }^{\circ} \mathrm{C}, 200{ }^{\circ} \mathrm{C}, 220^{\circ} \mathrm{C}$, and $240{ }^{\circ} \mathrm{C}$ with a heating rate of $0.033{ }^{\circ} \mathrm{C} / \mathrm{min}$. The variables analyzed were the compressive strength parallel to the fibers, compressive modulus of the elasticity parallel to the fibers, modulus of resistance of the wood to flexion, flexural modulus of elasticity, tensile strength parallel to the fibers, and shear parallel to the wood fibers. The results showed that there was no substantial evidence that heat treatment affects the stiffness of the wood samples. However, a notable decrease in the material strength was reported.

Araújo (2010) found that the Janka hardness values of various wood species were not improved much by heat treatment. Moura and Brito (2008) also studied the effects of heat treatment of Pinus caribaea var. hondurensis and E. grandis on the mechanical and finishing properties. The heat treatments were done in the presence and absence of oxygen at $140{ }^{\circ} \mathrm{C}, 160{ }^{\circ} \mathrm{C}, 180{ }^{\circ} \mathrm{C}$, and $200{ }^{\circ} \mathrm{C}$. The heat-treated samples were sanded with grit sizes of 80 mesh, 100 mesh, and 120 mesh. According to these authors, there was a decrease in the mechanical wood properties, and there was a higher penetration of the abrasive grains during sanding. The mean roughness in this study increased substantially in the heatedtreated samples.

Salca and Hiziroglu (2014) studied the influence of heat treatment on the hardness and roughness of four wood species: Alnus glutinosa L., Quercus falcata Michx., P. taeda L., and Liriodendron tulipifera L. The treatments were performed at $120{ }^{\circ} \mathrm{C}$ and $190{ }^{\circ} \mathrm{C}$ with exposure times of $3 \mathrm{~h}$ and $6 \mathrm{~h}$. The authors concluded that the heat treatment improved the surface quality of all of the wood species, but the hardness decreased. According to Ibach (2010), all thermally treated timber samples can be glued or painted and can also be used to manufacture furniture, floors, doors, window components, and other products.

There are few reports available that have studied the effect of heat treatment on the surface quality during the sanding process. Therefore, it was important to analyze the influence of wood heat treatment before sanding to evaluate the surface quality of the wood through the roughness $\left(R_{a}\right)$. 


\section{EXPERIMENTAL}

\section{Preparation of the Corymbia citriodora Samples}

The samples were prepared from Corymbia citriodora wood, with a density of $959.1 \mathrm{~kg} / \mathrm{m}^{3}$ at a $12 \%$ moisture content and a basic density of $731.7 \mathrm{~kg} / \mathrm{m}^{3}$. The basic density was determined according to ABNT NBR 11.941 (2003), in which the density values were obtained with Eq. 1,

$$
d_{b}=\frac{m_{3}}{\left(m_{2}-m_{1}\right)}
$$

where $d_{b}$ is the basic density of wood in $\mathrm{g} / \mathrm{cm}^{3} ; m_{3}$ is the mass of the oven dried sample at $(105 \pm 2){ }^{\circ} \mathrm{C}$, in grams $(\mathrm{g}) ; m_{2}$ is the mass of the vessel with water and immersed sample, in grams $(\mathrm{g})$; and $m_{1}$ is the mass of the container with water, in grams $(\mathrm{g})$. The volume of the sample corresponds to the volume of the displaced water, which in turn is equal to the mass difference $\left(m_{2}-m_{1}\right)$, considering the water density as one gram per cubic centimeter $\left(\mathrm{g} / \mathrm{cm}^{3}\right)$.

The $C$. citriodora wood was purchased at a sawmill in the city of Bauru (Brazil) and was obtained from large trees with a minimum diameter of $50 \mathrm{~cm}$ and age of approximately 35 years. The samples were produced in the Wood Processing Laboratory at São Paulo State University (UNESP, Itapeva, Brazil). The dimensions of the samples used were $54 \mathrm{~mm} \times 30 \mathrm{~mm} \times 23 \mathrm{~mm}$ (length $\times$ width $\times$ thickness).

The research was conducted using a horizontal sander that was driven pneumatically with an automatic testing system. The wood samples were sanded parallel to the grain. Sandpaper made of aluminum oxide with two different grit sizes (120 mesh and $80 \mathrm{mesh})$ was used at a cutting speed of $11 \mathrm{~m} / \mathrm{s}$ and specific pressure of $1 \mathrm{kgf} / \mathrm{cm}^{2}(98.1$ $\mathrm{kPa})$.

\section{Heat Treatment and Wood Sanding}

For the preparation of the wood samples for heat treatment, 36 samples were placed in a climatic chamber to stabilize the moisture content to $12 \%$. Afterwards, the samples were placed in the kiln for the heat treatment, and the heating was started at a rate of approximately $1.8^{\circ} \mathrm{C} / \mathrm{min}$ until the desired treatment temperature was reached. The samples were then left for 2 hours at the temperature reached, and soon after, the kiln was switched off until it cooled to room temperature. Three temperatures of $120{ }^{\circ} \mathrm{C}, 160{ }^{\circ} \mathrm{C}$, and $200{ }^{\circ} \mathrm{C}$ were employed (Almeida et al. 2013). Twelve samples were heat-treated at each temperature.

The sanding process was conducted on the heat-treated samples. These samples were placed with their surfaces sanded parallel to the grain in a flat sander, using an automatic feed system with two different sandpaper grit sizes (80 and 120 mesh). Additionally, 12 control samples with a $12 \%$ moisture content were sanded at room temperature. After sanding the samples, their surfaces were evaluated six times by measuring their $R_{a}$ values in the direction perpendicular to the grain using a roughness meter.

\section{Measurement of the Average Roughness}

The roughness parameter obtained was from the mean $R_{a}$ values. This was the best fit to the surface finishing of the wood samples because of their anatomy. The sampling length was set at $2.5 \mathrm{~mm}$ (cut-off), as was suggested by ABNT NBR ISO 4287 (2002). The 
measuring course with the $2.5-\mathrm{mm}$ cut-off was $12.5 \mathrm{~mm}$, which resulted in an average of five measurement values being acquired. The range adopted in the rugosimeter was 300 $\mu \mathrm{m}$. To measure the surface roughness, a roughness meter (Surtronic 25+, Taylor Hobson, La Roca del Vallés, Spain) with a cone-spherical diamond-like measuring stem and radius of $2 \mu \mathrm{m}$ was used.

\section{Data Evaluation}

For the evaluation of the results, a full cross-factorial design $(2 \times 4)$ was used, where the first factor was the sandpaper grit with two mesh levels (80 mesh and 120 mesh), and the second factor was the heat treatment with four temperatures (control, $120{ }^{\circ} \mathrm{C}, 160{ }^{\circ} \mathrm{C}$, and $200{ }^{\circ} \mathrm{C}$ ). The data were analyzed with an analysis of variance (ANOVA) using the software R (version 3.3.1, Statistical Computing, Vienna, Austria). Multiple Tukey comparison tests between the grit size and heat treatment temperature were done using Tukey's honest significant difference test.

\section{RESULTS AND DISCUSSION}

Table 1 shows the general and marginal averages, as well as the standard deviations and errors of the surface roughness values for the various heat treatment temperatures and sandpaper grit sizes. Table 1 also gives the results of the ANOVA.

Table 1. Surface Roughness Values under Various Conditions of Sanding of the C. citriodora

\begin{tabular}{|c|c|c|c|c|c|c|}
\hline \multicolumn{2}{|c|}{ Factor } & \multirow{2}{*}{$\begin{array}{l}\text { Number of } \\
\text { Samples }\end{array}$} & \multirow{2}{*}{$\begin{array}{c}\text { Average } \\
\text { Roughness } \\
(\mu \mathrm{m})\end{array}$} & \multirow{2}{*}{$\begin{array}{l}\text { Standard } \\
\text { Deviation }\end{array}$} & \multirow{2}{*}{$\begin{array}{c}\text { Standard } \\
\text { Error }\end{array}$} & \multirow{2}{*}{$\begin{array}{c}\text { Coefficient } \\
\text { of } \\
\text { Variation } \\
(\%)\end{array}$} \\
\hline $\begin{array}{l}\text { Sandpaper } \\
\text { Grit Size }\end{array}$ & $\begin{array}{l}\text { Temp. } \\
\left({ }^{\circ} \mathrm{C}\right)\end{array}$ & & & & & \\
\hline \multirow{4}{*}{80} & Control & 6 & 7.45 & 0.659 & 0.269 & 8.8 \\
\hline & 120 & 6 & 7.33 & 0.698 & 0.285 & 9.5 \\
\hline & 160 & 6 & 7.23 & 0.383 & 0.156 & 5.3 \\
\hline & 200 & 6 & 8.27 & 0.712 & 0.291 & 8.6 \\
\hline \multirow{4}{*}{120} & Control & 6 & 6.27 & 0.403 & 0.165 & 6.4 \\
\hline & 120 & 6 & 5.27 & 0.446 & 0.182 & 8.5 \\
\hline & 160 & 6 & 5.47 & 0.546 & 0.223 & 10.0 \\
\hline & 200 & 5 & 6.82 & 0.850 & 0.380 & 12.5 \\
\hline \multicolumn{7}{|c|}{ Marginal Average Roughness $(\mu \mathrm{m})$ for Each Factor Level } \\
\hline \multicolumn{2}{|c|}{80 mesh } & 120 mesh & Control & $120^{\circ} \mathrm{C}$ & $160^{\circ} \mathrm{C}$ & $200^{\circ} \mathrm{C}$ \\
\hline \multicolumn{2}{|c|}{7.57} & 5.96 & 6.86 & 6.30 & 6.35 & 7.54 \\
\hline \multicolumn{2}{|c|}{$\begin{array}{c}\text { ANOVA and } \\
\text { SV }\end{array}$} & DF & SS & MS & $\mathrm{F}$ & $P(>F)$ \\
\hline \multicolumn{2}{|c|}{ Sandpaper } & 1 & 32.11 & 32.11 & 87.68 & $7.69 \mathrm{e}-12$ \\
\hline \multicolumn{2}{|c|}{ Temperature } & 3 & 11.26 & 3.75 & 10.25 & $3.44 \mathrm{e}-05$ \\
\hline \multicolumn{2}{|c|}{ Residues } & 42 & 15.38 & 0.37 & - & - \\
\hline \multicolumn{2}{|c|}{ Total } & 46 & 58.75 & - & - & - \\
\hline
\end{tabular}

SV: source of variation; DF: degrees of freedom; SQ: sum of squares; MS: mean square; The $\mathrm{F}$ and $\mathrm{P}$ values are expressed at significance levels of $\alpha=5 \%$. 
There was no interaction between the sandpaper grit size and heat treatment temperature $(\mathrm{P}$ value $=0.316)$ at a $5 \%$ significance level, as is shown in Fig. 1.

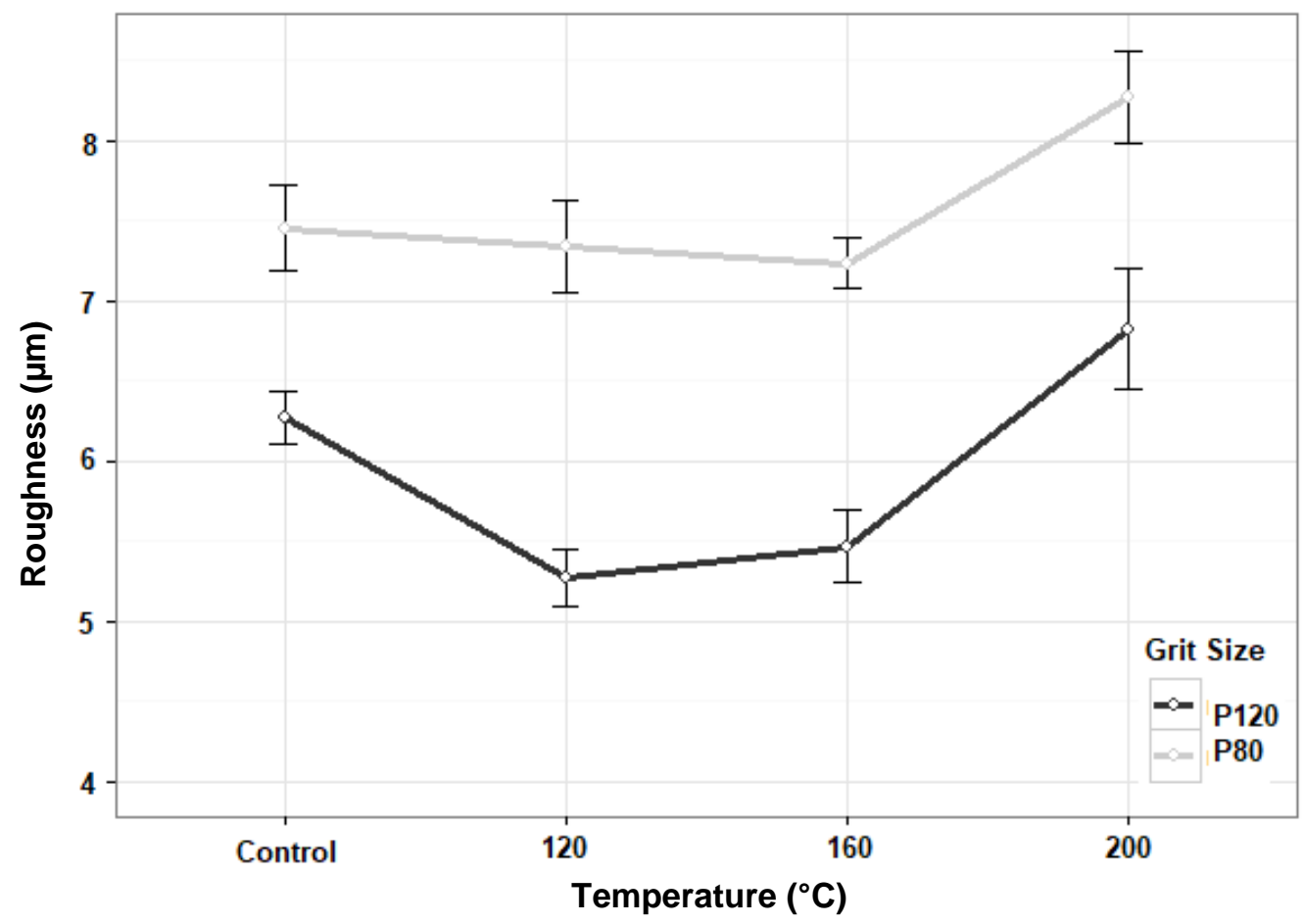

Fig. 1. Graph of the interaction between the roughness and heat treatment temperature for different grit sizes

While analyzing the main effects, significant differences were found between the two sandpaper mesh sizes $(\mathrm{P}$ value $=7.69 \mathrm{e}-12)$ and between the three temperatures $(\mathrm{P}$ value $=3.44$ e-05). Figure 2 shows the distribution of the data for the sandpaper grit sizes and heat treatment temperatures. The gray dots represent the average values for each factor level.

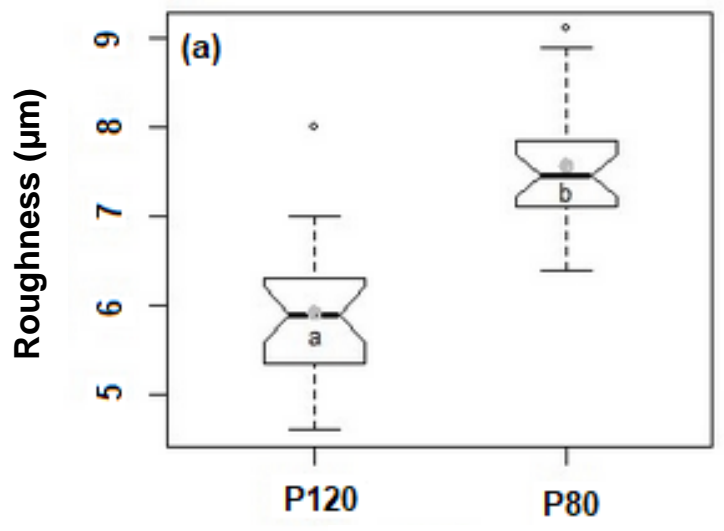

Grit Size

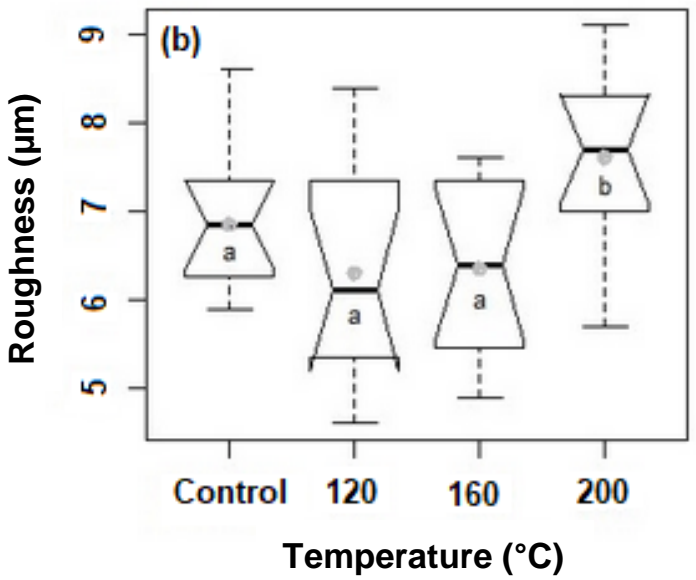

Temperature $\left({ }^{\circ} \mathrm{C}\right)$

Fig. 2. Distribution of the average roughness of the $C$. citriodora samples for different (a) sandpaper grit sizes and (b) heat treatment temperatures; different letters represent significant differences between the groups ( $P$ value $<0.05)$; gray dots are the average values 
It was found that there were no significant differences between the temperatures of $120{ }^{\circ} \mathrm{C}$ and $160{ }^{\circ} \mathrm{C}$ compared with the control samples. However, these three levels had significantly lower roughness values when compared with those obtained at $200{ }^{\circ} \mathrm{C}$. The sandpaper mesh size of 80 and the temperature of $200{ }^{\circ} \mathrm{C}$ had the highest roughness values for this wood species and differed significantly from the other studied levels.

This result was explained by the work of Molina and da Silva (2012), who studied the effects of heat treatment on the strength and stiffness of E. citriodora, and noted a significant reduction in the material strength. Thus, it was inferred that the heat treatment caused the decrease in the wood resistance, and consequently the 80-mesh grit size pulled more material and produced higher roughness values.

Figure 3 shows a bar graph of the roughness as function of the temperature for both sandpaper grit sizes. The differences in the roughness values were large between the sandpaper grit sizes for the control and treated samples. Each bar contained the standard deviation for each combination of the sandpaper grit size and temperature with confidence intervals of $95 \%$.

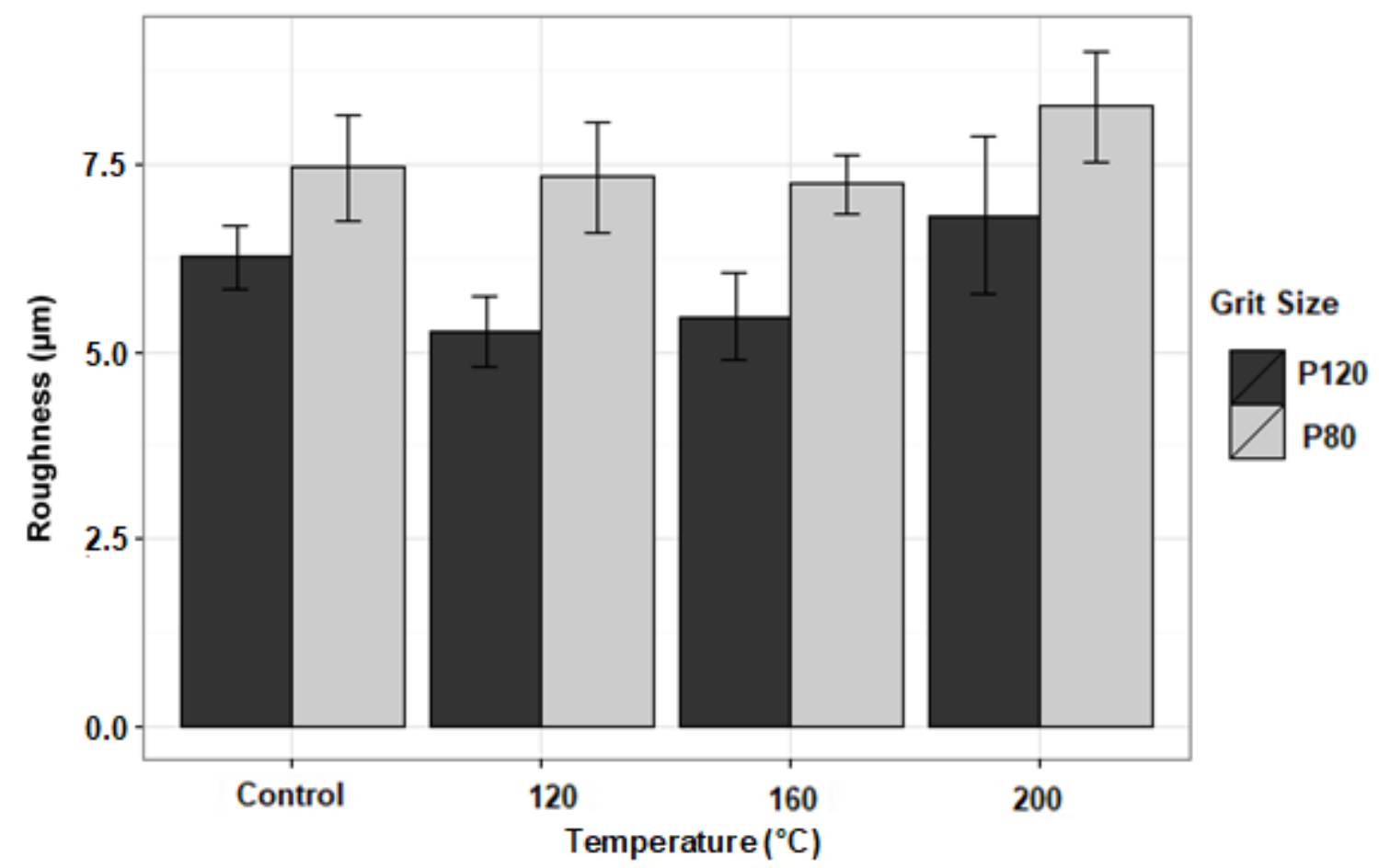

Fig. 3. Bar chart with standard deviations of the roughness as a function of the heat treatment temperature for different sandpaper grit sizes

\section{CONCLUSIONS}

1. The best surface finish of the C. citriodora samples was obtained with the 120-mesh sandpaper grit size at lower temperatures. However, a significant increase in the roughness of the wood samples was observed for both sandpaper mesh sizes after heat treatment at $200{ }^{\circ} \mathrm{C}$. 
2. This study showed that heat treatment at temperatures up to $160{ }^{\circ} \mathrm{C}$ did not decrease the wood surface quality. Therefore, up to this temperature, the benefits from heat treatment, including the best wettability, resistance to fungi and insect attack, and others, can be obtained without losing the wood surface quality after sanding.

\section{ACKNOWLEDGEMENTS}

The author acknowledges the financial support from the Foundation for Research of the State of São Paulo (FAPESP) through a trainee grant.

\section{REFERENCES CITED}

ABNT NBR ISO 4287 (2002). "Rugosidade das superficies [Surface roughness]," Brazilian National Standards Organization, Rio de Janeiro, Brazil.

ABNT NBR 11.941 (2003). "Madeira - Determinação da densidade básica [Wood Determination of basic density]," Brazilian National Standards Organization, Rio de Janeiro, Brazil.

Almeida, C. C., Lima, L. R., and Alves, M. C. S. (2013). "Effects of thermal treatments of wood in the sanding process of Corymbia citriodora," in: COBEM - $22^{\text {nd }}$ International Congress of Mechanical Engineering, Ribeirão Preto, Brazil.

Araújo, S. O. (2010). Propriedades de Madeiras Termorretificadas [Properties of Heattreated Wood], Ph.D. Dissertation, Universidade Federal de Viçosa, Viçosa, Brazil.

Bhuiyan, M. T. R., Hirai, N., and Sobue, N. (2000). "Changes of crystallinity in wood cellulose by heat treatment under dried and moist conditions," J. Wood Sci. 46(6), 431-436. DOI: 10.1007/BF00765800

González-Peña, M. M., Curling, S. F., and Hale, M. D. C. (2009). "On the effect of heat on the chemical composition and dimensions of thermally-modified wood," Polym. Degrad. Stabil. 94(12), 2184-2193. DOI: 10.1016/j.polymdegradstab.2009.09.003

Gündüz, G., Korkut, S., and Korkut, D. S. (2008). "The effects of heat treatment on physical and technological properties and surface roughness of Camiyanı black pine (Pinus nigra Arn. subsp. pallasiana var. pallasiana) wood," Bioresource Technol. 99(7), 2275-2280. DOI: 10.1016/j.biortech.2007.05.015

Hendarto, B., Shayan, E., and Ozarska, B. (2004). Characterisation of Surface Finishing Processes in Wood Furniture Manufacturing, CRC Wood Innovations, Melbourne, Australia.

Ibach, R. E. (2010). "Specialty treatments," in: Wood Handbook: Wood as an Engineering Material, Forest Products Laboratory, Madison, WI, U.S. Department of Agriculture, Forest Service.

Kačíková, D., Kačík, F., Čabalová, I., and Ďurkovič, J. (2013). "Effects of thermal treatment on chemical, mechanical and colour traits in Norway spruce wood," Bioresource Technol. 144, 669-674. DOI: 10.1016/j.biortech.2013.06.110

Molina, J. C., and da Silva, K. C. R. (2012). "Efeito da termorretificação nas propriedades de resistência e de rigidez da madeira Eucalipto citriodora [Effect of thermoregulation on the strength and stiffness properties of Eucalyptus citriodora wood]," Madeira: Arquitetura e Engenharia 13(33), 53-68. 
Moura, L. F., and Brito, J. O. (2008). "Effect of thermal treatment on machining properties of Eucalyptus grandis and Pinus caribaea var. hondurensis woods," in: Proceedings of the $51^{\text {st }}$ International Convention of Society of Wood Science and Technology, Concepción, Chile, pp. 1-9.

Navi, P., and Sandberg, D. (2012). "Heat treatment," in: Thermo-Hydro-Mechanical Processing of Wood, CRC Press, Boca Raton, FL, pp. 287-354.

Poubel, D. S., Garcia, R. A., Santos, W. A., Oliveira, G. L., and Abreu, H. S. (2013). "Efeito da termorretificação nas propriedades físicas e químicas da madeira de Pinus carieba [Effect of thermortification on the physical and chemical properties of Pinus carieba wood]," Cerne 19(3), 391-398.

R Core Team (2016). "R: A language and environment for statistical computing," $R$ Foundation for Statistical Computing, Vienna, Austria, (https://www.R-project.org/).

Rodrigues, T. O. (2009). Efeito da Torrefação no Condicionamento de Biomassa para Fins Energéticos [Effect of Torrefaction on Biomass Conditioning for Energy Purposes], Master's Thesis, Universidade de Brasília, Brasília, Brazil.

Salca, E.-A., and Hiziroglu, S. (2014). "Evaluation of hardness and surface quality of different wood species as function of heat treatment," Mater. Design 62, 416-423. DOI: $10.1016 /$ j.matdes.2014.05.029

Saloni, D. E., Lemaster, R. L., and Jackson, S. D. (2010). "Process monitoring evaluation and implementation for the wood abrasive machining process," Sensors 10(11), 10401-10412. DOI: 10.3390/s101110401

Sweet, M. S., and Winandy, J. E. (1999). "Influence of degree of polymerization of cellulose and hemicellulose on strength loss in fire-retardant-treated southern pine," Holzforschung 53(3), 311-317. DOI: 10.1515/HF.1999.051

Wikberg, H., and Maunu, S. L. (2004). "Characterisation of thermally modified hard- and softwoods by ${ }^{13}$ C CPMAS NMR,” Carbohyd. Polym. 58(4), 461-466. DOI: 10.1016/j.carbpol.2004.08.008

Yildiz, S., Gezer, E. D., and Yildiz, U. C. (2006). "Mechanical and chemical behavior of spruce wood modified by heat," Build. Environ. 41(12), 1762-1766. DOI: 10.1016/j.buildenv.2005.07.017

Yildiz, S., and Gümüşkaya, E. (2007). "The effects of thermal modification on crystalline structure of cellulose in soft and hardwood," Build. Environ. 42(1), 62-67. DOI: 10.1016/j.buildenv.2005.07.009

Article submitted: July 11, 2018; Peer review completed: December 31, 2018; Revised version received: January 30, 2019; Accepted: February 5, 2019; Published: February 8, 2019. DOI: 10.15376/biores.14.2.2576-2583 